\title{
GENETIC DIVERSITY OF RHIZOBIA ISOLATES FROM AMAZON SOILS USING COWPEA (VIGNA UNGUICULATA) AS TRAP PLANT
}

\author{
Silva, F.V. ${ }^{*}$; Simões-Araújo, J.L. ${ }^{2}$; Silva Júnior, J.P. ${ }^{3}$; Xavier, G.R. ${ }^{2}$; Rumjanek, N.G. ${ }^{2}$ \\ ${ }^{1}$ Departamento de Ciências, Universidade do Estado do Rio de Janeiro, São Gonçalo, RJ, Brasil; ${ }^{2}$ Embrapa Agrobiologia, \\ Seropédica, RJ, Brasil; ${ }^{3}$ Embrapa Trigo, Passo Fundo, RS, Brasil.
}

Submitted: March 26, 2011; Returned to authors for corrections: September 02, 2011; Approved: January $16,2012$.

\begin{abstract}
The aim of this work was to characterize rhizobia isolated from the root nodules of cowpea (Vigna unguiculata) plants cultivated in Amazon soils samples by means of ARDRA (Amplified rDNA Restriction Analysis) and sequencing analysis, to know their phylogenetic relationships. The 16S rRNA gene of rhizobia was amplified by PCR (polymerase chain reaction) using universal primers Y1 and Y3. The amplification products were analyzed by the restriction enzymes HinfI, MspI and DdeI and also sequenced with Y1, Y3 and six intermediate primers. The clustering analysis based on ARDRA profiles separated the Amazon isolates in three subgroups, which formed a group apart from the reference isolates of Bradyrhizobium japonicum and Bradyrhizobium elkanii. The clustering analysis of 16S rRNA gene sequences showed that the fast-growing isolates had similarity with Enterobacter, Rhizobium, Klebsiella and Bradyrhizobium and all the slow-growing clustered close to Bradyrhizobium.
\end{abstract}

Key words: BNF, bacteria, 16S rRNA, ARDRA, sequencing.

\section{INTRODUCTION}

The interaction between legume-diazotrophic bacteria is an example of biological association intensely studied, whose benefits for agricultural sustainability are well known, basically as a consequence of the biological nitrogen fixation process (BNF) and their effect on plant growth and production.

The changes in rhizobia taxonomy happened during the last decade according the increase of information about phenetic and genetic properties of this group of bacteria (18).
An example was the debate when the Subcommittee on the Taxonomy of Agrobacterium and Rhizobium disagreed with the justification of the Judicial Comission that considered the genus Sinorhizobium not validly published because it is a later synonym of Ensifer (14). In response, the Judicial Commission confirmed Ensifer as the correct name for the genus (28). The rhizobia phylogeny based on $16 \mathrm{~S}$ rRNA showed that it can be organized into five genera: Bradyrhizobium, Azorhizobium, Ensifer (Sinorhizobium), Mesorhizobium and Rhizobium (18, 25). The Rhizobium genus was united with Agrobacterium and

*Corresponding Author. Mailing address: Departamento de Ciências, Universidade do Estado do Rio de Janeiro, São Gonçalo, Rio de Janeiro, Brasil.; E-mail: flavia_venancio@uerj.br 
Allorhizobium, because of their close relation (27). New diazotrophic symbiotic bacteria have been classified in others genera outside rhizobial ones $(18,25)$.

Most of the rhizobia that form nodules in leguminous taxonomically distant from native Amazon forest plant species were classified as Bradyrhizobium (16). The characterization of Amazon rhizobia has indicated that different crop systems can change the diversity and some isolates have potential for agronomic tests $(8,13)$. Actually, the isolates INPA-11B (from Manaus, with $98 \%$ of similarity with $B$. elkanii), UFLA3-84 (from Rondônia, with $97 \%$ of similarity with Bradyrhizobium sp.) and BR3267 (Bradyrhizobium sp. from semi-arid) have been recommended for inoculation to cowpea (Vigna unguiculata) (17).

Although some studies of rhizobia in Amazon soils have already been done, taxonomy of those isolates is also unknown. The aim of this work was to characterize rhizobia isolated from the root nodules of cowpea plants cultivated in Amazon soils samples by means of ARDRA and sequencing analysis, to know their phylogenetic relationships in addition to their cultural and morphological characterization.

\section{MATERIALS AND METHODS}

\section{Soil samples}

The samples of soils were collected from the following six areas: native forest, 18 years old reclamation area, 5 years old reclamation area, 5 years old reclamation area enriched with Parkia multijuga, Swietenia macrophylla, Bertholletia excelsa and Hevea brasiliensis, polyculture plot (Bertholletia excelsa, Bactris gasipaes, Theobroma grandiflorum) and monoculture plot (Theobroma grandiflorum). The experimental area was localized at Embrapa Agrofloresta, $40 \mathrm{Km}$ from Manaus, AM. The soil samples were mixed with sand (1:2,w:w) since this strategy diminishes the amount of nitrogen available for the plants development and, in consequence, stimulates the nodulation of roots by the rhizobia. The mixture was placed in pots (300 g) and cowpea (Vigna unguiculata) was used as trap host for rhizobia in a greenhouse.

The seeds were sown in triplicate for each soil sample. Seeds surface was sterilized by immersion in ethanol $(70 \% ; 30$ sec), and hydrogen peroxide $(5 \% ; 3 \mathrm{~min})$, being then washed 10 times with sterile distilled water. Nutrient solution without nitrogen (19) was added weekly to seeds cultivation, along the entire growth period of the plants. Sterile water was added whenever needed. Two plants per pot were harvested 60 days after sowing. Roots were washed and nodules were detached and dried in flasks containing silica gel.

\section{Isolation of rhizobia from nodules and morphological characterization}

Thirty nodules from six plants of each treatment were random chosen and surface sterilized by ethanol (70\%; $30 \mathrm{sec})$, $\mathrm{NaOCl}(5 \% ; 4$ min) and washed 10 times with sterile water. Crushed nodules were streaked onto yeast manitol agar medium (YMA) containing bromothymol blue (4) and incubated at $28^{\circ} \mathrm{C}$. The evaluated morphological traits comprised mucous production and colony morphology, $\mathrm{pH}$ change of the medium during growth of the isolates and growth rate. Mucous production analysis was based on type, consistency and appearance, while colony morphology parameters were diameter, form, elevation and optics. According to the growth rate in culture medium, the isolates were characterized as fast-growing (colonies formed after one or two days on the culture medium) or slow-growing (colonies formed with four days on the culture medium). The Amazon isolates were deposited in the diazotroph culture collection of Embrapa Agrobiologia. Table 1 provides information of the Amazon isolates that were analyzed by ARDRA and $16 \mathrm{~S}$ rRNA sequencing. Some isolates listed at Table 1 were effectively analyzed by ARDRA, but their 16S rRNA was not completely sequenced after some attempts and, consequently, they do not present an access number; however, others isolates with similar cultural and morphological characteristics were effectively sequenced. 
Table 1. The origin, cultural and morphological characteristics and access number in the Gene bank of the Amazon isolates analyzed by ARDRA and/or 16S rRNA.

\begin{tabular}{|c|c|c|c|c|c|c|c|c|c|c|c|c|}
\hline Isolate & Area & GR & pH & CM & TM & $\mathbf{A M}$ & $\mathbf{O}$ & D & $\mathbf{F}$ & $\mathbf{E}$ & B & Accession \\
\hline BR3303 & $\mathrm{NF}$ & $\mathrm{S}$ & AL & FL & W & $\mathrm{He}$ & $\mathrm{O} / \mathrm{T}$ & $>1 \mathrm{~mm}$ & I & $\mathrm{P}$ & $\mathrm{S}$ & HQ641215 \\
\hline BR3304 & $\mathrm{NF}$ & $\mathrm{F}$ & AL & $\mathrm{V}$ & $\mathrm{D}$ & Ho & $\mathrm{O} / \mathrm{T}$ & $>1 \mathrm{~mm}$ & I & $\mathrm{P}$ & $\mathrm{R}$ & HQ641216 \\
\hline BR3305 & $\mathrm{NF}$ & $\mathrm{S}$ & AL & FL & W & $\mathrm{He}$ & $\mathrm{O}$ & $1 \mathrm{~mm}$ & I & $\mathrm{P}$ & S & HQ641217 \\
\hline BR3306 & $5 \mathrm{YOE}$ & $S$ & AL & FL & W & $\mathrm{He}$ & $\mathrm{T}$ & $1 \mathrm{~mm}$ & $\mathrm{C}$ & $\mathrm{P}$ & S & HQ641212 \\
\hline BR3307 & $18 \mathrm{YO}$ & $\mathrm{S}$ & $\mathrm{AL}$ & FL & W & $\mathrm{He}$ & $\mathrm{T}$ & $>1 \mathrm{~mm}$ & $\mathrm{C}$ & $\mathrm{P}$ & S & HQ641211 \\
\hline BR3308 & $5 \mathrm{YO}$ & S & $\mathrm{AL}$ & FL & $\mathrm{W}$ & $\mathrm{He}$ & $\mathrm{T}$ & $>1 \mathrm{~mm}$ & I & $\mathrm{P}$ & S & HQ641210 \\
\hline BR3309 & $\mathrm{PO}$ & S & $\mathrm{AL}$ & FL & $\mathrm{W}$ & $\mathrm{He}$ & $\mathrm{T}$ & $1 \mathrm{~mm}$ & $\mathrm{C}$ & $\mathrm{P}$ & S & HQ641213 \\
\hline BR3310 & $\mathrm{PO}$ & S & $\mathrm{AL}$ & FL & $\mathrm{W}$ & $\mathrm{He}$ & $\mathrm{T}$ & $>1 \mathrm{~mm}$ & $\mathrm{C}$ & $\mathrm{P}$ & S & HQ641214 \\
\hline BR3312 & $5 \mathrm{YOE}$ & S & $\mathrm{AC}$ & FL & $\mathrm{W}$ & $\mathrm{He}$ & $\mathrm{O}$ & $>1 \mathrm{~mm}$ & $\mathrm{C}$ & $\mathrm{P}$ & S & HQ641218 \\
\hline BR3315 & $5 \mathrm{YOE}$ & S & $\mathrm{AC}$ & FL & W & $\mathrm{He}$ & $\mathrm{O}$ & $1 \mathrm{~mm}$ & $\mathrm{C}$ & $\mathrm{P}$ & S & HQ641219 \\
\hline BR3316 & $5 \mathrm{YOE}$ & $\mathrm{S}$ & $\mathrm{AL}$ & FL & W & $\mathrm{He}$ & $\mathrm{O}$ & $1 \mathrm{~mm}$ & $\mathrm{C}$ & $\mathrm{P}$ & S & HQ641220 \\
\hline BR3319 & $5 \mathrm{YOE}$ & S & $\mathrm{AL}$ & FL & W & $\mathrm{He}$ & $\mathrm{O}$ & $>1 \mathrm{~mm}$ & I & $\mathrm{P}$ & S & ------------- \\
\hline BR3321 & $5 \mathrm{YOE}$ & S & $\mathrm{AL}$ & FL & $\mathrm{W}$ & $\mathrm{He}$ & $\mathrm{O}$ & $>1 \mathrm{~mm}$ & $\mathrm{C}$ & $\mathrm{P}$ & S & HQ641221 \\
\hline BR3323 & $5 \mathrm{YOE}$ & S & $\mathrm{AC}$ & FL & W & $\mathrm{He}$ & $\mathrm{T}$ & $<1 \mathrm{~mm}$ & $\mathrm{C}$ & $\mathrm{P}$ & S & HQ641222 \\
\hline BR3324 & MO & $\mathrm{S}$ & AL & $\mathrm{V}$ & W & Ho & $\mathrm{O}$ & $<1 \mathrm{~mm}$ & $\mathrm{C}$ & $\mathrm{P}$ & $S$ & HQ641232 \\
\hline BR3325 & MO & S & $\mathrm{AC}$ & FL & $\mathrm{D}$ & $\mathrm{He}$ & $\mathrm{O}$ & $>1 \mathrm{~mm}$ & I & $\mathrm{P}$ & S & HQ641233 \\
\hline BR3326 & MO & S & $\mathrm{AL}$ & FL & $\mathrm{W}$ & $\mathrm{He}$ & $\mathrm{O}$ & $>1 \mathrm{~mm}$ & $\mathrm{C}$ & $\mathrm{P}$ & S & ------------- \\
\hline BR3327 & MO & $\mathrm{S}$ & $\mathrm{AL}$ & FL & W & $\mathrm{He}$ & $\mathrm{O}$ & $>1 \mathrm{~mm}$ & $\mathrm{C}$ & $\mathrm{P}$ & S & HQ641234 \\
\hline BR3329 & MO & $\mathrm{S}$ & $\mathrm{AL}$ & FL & $\mathrm{W}$ & $\mathrm{He}$ & $\mathrm{O}$ & $<1 \mathrm{~mm}$ & $\mathrm{C}$ & $\mathrm{P}$ & S & HQ641235 \\
\hline BR3330 & $\mathrm{MO}$ & $\mathrm{S}$ & AL & FL & W & $\mathrm{He}$ & $\mathrm{O}$ & $>1 \mathrm{~mm}$ & I & $\mathrm{P}$ & S & HQ641236 \\
\hline BR3331 & MO & $\mathrm{S}$ & AL & FL & W & $\mathrm{He}$ & $\mathrm{O}$ & $>2 \mathrm{~mm}$ & $\mathrm{C}$ & $\mathrm{P}$ & S & HQ641237 \\
\hline BR3332 & MO & $\mathrm{S}$ & $\mathrm{AL}$ & FL & W & $\mathrm{He}$ & $\mathrm{O}$ & $2 \mathrm{~mm}$ & I & $\mathrm{P}$ & S & HQ641238 \\
\hline BR3333 & MO & S & $\mathrm{AL}$ & FL & W & $\mathrm{He}$ & $\mathrm{O}$ & $2 \mathrm{~mm}$ & I & $\mathrm{P}$ & $S$ & HQ641239 \\
\hline BR3334 & MO & S & $\mathrm{AL}$ & FL & W & $\mathrm{He}$ & $\mathrm{O}$ & $>1 \mathrm{~mm}$ & I & $\mathrm{P}$ & $S$ & HQ641240 \\
\hline BR3335 & MO & S & AL & FL & W & $\mathrm{He}$ & $\mathrm{O}$ & $1 \mathrm{~mm}$ & I & $\mathrm{P}$ & S & HQ641241 \\
\hline BR3336 & $\mathrm{PO}$ & S & AL & FL & $\mathrm{W}$ & $\mathrm{He}$ & $\mathrm{O}$ & $1 \mathrm{~mm}$ & $\mathrm{C}$ & $\mathrm{P}$ & $S$ & HQ641250 \\
\hline BR3337 & $\mathrm{PO}$ & $\mathrm{F}$ & $\mathrm{AC}$ & $\mathrm{V}$ & $\mathrm{W}$ & Ho & $\mathrm{T}$ & $2 \mathrm{~mm}$ & $\mathrm{C}$ & E & S & HQ641251 \\
\hline BR3339 & $\mathrm{PO}$ & $\mathrm{S}$ & $\mathrm{AL}$ & FL & $\mathrm{W}$ & $\mathrm{He}$ & $\mathrm{O}$ & $>1 \mathrm{~mm}$ & $\mathrm{C}$ & $\mathrm{P}$ & S & HQ641252 \\
\hline BR3340 & $\mathrm{PO}$ & $S$ & $\mathrm{AL}$ & FL & $\mathrm{W}$ & $\mathrm{He}$ & $\mathrm{O}$ & $1 \mathrm{~mm}$ & $\mathrm{C}$ & $\mathrm{P}$ & S & HQ641253 \\
\hline BR3341 & $\mathrm{PO}$ & $\mathrm{F}$ & $\mathrm{AC}$ & $\mathrm{V}$ & $\mathrm{W}$ & $\mathrm{He}$ & $\mathrm{T}$ & $3 \mathrm{~mm}$ & I & $\mathrm{P}$ & S & HQ677829 \\
\hline BR3342 & $\mathrm{PO}$ & $\mathrm{S}$ & AL & FL & $\mathrm{W}$ & $\mathrm{He}$ & $\mathrm{O}$ & $>1 \mathrm{~mm}$ & I & $\mathrm{P}$ & S & ------------- \\
\hline BR3343 & $\mathrm{PO}$ & $\mathrm{S}$ & $\mathrm{AL}$ & FL & $\mathrm{W}$ & $\mathrm{He}$ & $\mathrm{O}$ & $>1 \mathrm{~mm}$ & $\mathrm{C}$ & $\mathrm{P}$ & S & ------------- \\
\hline BR3345 & $18 \mathrm{YO}$ & $\mathrm{S}$ & $\mathrm{AL}$ & FL & W & $\mathrm{He}$ & $\mathrm{O}$ & $>1 \mathrm{~mm}$ & $\mathrm{C}$ & $\mathrm{P}$ & S & HQ641223 \\
\hline BR3346 & $18 Y O$ & S & AL & FL & $\mathrm{W}$ & $\mathrm{He}$ & $\mathrm{O}$ & $>1 \mathrm{~mm}$ & $\mathrm{C}$ & $\mathrm{P}$ & $S$ & HQ641224 \\
\hline BR3350 & $18 \mathrm{YO}$ & S & AL & FL & W & $\mathrm{He}$ & $\mathrm{O}$ & $>1 \mathrm{~mm}$ & $\mathrm{C}$ & $\mathrm{P}$ & S & HQ641225 \\
\hline BR3351 & $18 \mathrm{YO}$ & $\mathrm{S}$ & $\mathrm{AL}$ & FL & W & $\mathrm{He}$ & $\mathrm{O}$ & $>1 \mathrm{~mm}$ & $\mathrm{C}$ & $\mathrm{P}$ & S & HQ641226 \\
\hline BR3352 & $18 \mathrm{YO}$ & $\mathrm{F}$ & $\mathrm{AL}$ & FL & W & $\mathrm{He}$ & $\mathrm{T}$ & $<1 \mathrm{~mm}$ & $\mathrm{C}$ & $\mathrm{P}$ & S & HQ641227 \\
\hline BR3353 & $18 \mathrm{YO}$ & $\mathrm{S}$ & $\mathrm{AL}$ & FL & W & $\mathrm{He}$ & $\mathrm{O}$ & $1 \mathrm{~mm}$ & $\mathrm{C}$ & $\mathrm{P}$ & $S$ & ------ \\
\hline BR3354 & $\mathrm{NF}$ & $\mathrm{S}$ & $\mathrm{AL}$ & FL & W & $\mathrm{He}$ & $\mathrm{O} / \mathrm{T}$ & $3 \mathrm{~mm}$ & I & $\mathrm{P}$ & S & HQ641228 \\
\hline BR3355 & $\mathrm{NF}$ & $\mathrm{F}$ & $\mathrm{N}$ & $\mathrm{V}$ & W & Ho & $\mathrm{O} / \mathrm{T}$ & $3 \mathrm{~mm}$ & $\mathrm{C}$ & $\mathrm{E}$ & $S$ & HQ677827 \\
\hline BR3356 & NF & $\mathrm{S}$ & $\mathrm{AL}$ & FL & W & $\mathrm{He}$ & $\mathrm{O} / \mathrm{T}$ & $2 \mathrm{~mm}$ & I & $\mathrm{P}$ & S & HQ641229 \\
\hline BR3357 & $\mathrm{NF}$ & $\mathrm{F}$ & $\mathrm{AC}$ & $\mathrm{V}$ & $\mathrm{W}$ & $\mathrm{He}$ & $\mathrm{O} / \mathrm{T}$ & $7 \mathrm{~mm}$ & I & $\mathrm{P}$ & S & HQ677828 \\
\hline BR3358 & $\mathrm{NF}$ & $\mathrm{F}$ & $\mathrm{AC}$ & $\mathrm{V}$ & $\mathrm{D}$ & $\mathrm{He}$ & $\mathrm{O} / \mathrm{T}$ & $4 \mathrm{~mm}$ & I & $\mathrm{P}$ & $S$ & HQ677831 \\
\hline BR3359 & $\mathrm{NF}$ & $\mathrm{F}$ & $\mathrm{AC}$ & V & $\mathrm{D}$ & $\mathrm{He}$ & $\mathrm{O} / \mathrm{T}$ & $>7 \mathrm{~mm}$ & I & $\mathrm{P}$ & $\mathrm{R}$ & HQ677830 \\
\hline BR3360 & $\mathrm{NF}$ & $\mathrm{S}$ & $\mathrm{AL}$ & FL & W & $\mathrm{He}$ & $\mathrm{O} / \mathrm{T}$ & $2 \mathrm{~mm}$ & I & $\mathrm{P}$ & $S$ & HQ641230 \\
\hline BR3361 & $\mathrm{NF}$ & $\mathrm{S}$ & $\mathrm{AL}$ & FL & W & $\mathrm{He}$ & $\mathrm{O} / \mathrm{T}$ & $2 \mathrm{~mm}$ & I & $\mathrm{P}$ & S & HQ641231 \\
\hline BR3362 & NF & $\mathrm{F}$ & $\mathrm{AC}$ & $\mathrm{V}$ & D & Ho & $\mathrm{O} / \mathrm{T}$ & $5 \mathrm{~mm}$ & I & $\mathrm{P}$ & $\mathrm{R}$ & HQ677832 \\
\hline BR3363 & $5 \mathrm{YO}$ & S & $\mathrm{AC}$ & FL & W & $\mathrm{He}$ & $\mathrm{O}$ & $>1 \mathrm{~mm}$ & $\mathrm{C}$ & $\mathrm{P}$ & S & HQ641242 \\
\hline BR3365 & $5 \mathrm{YO}$ & S & $\mathrm{AL}$ & FL & $\mathrm{W}$ & $\mathrm{He}$ & $\mathrm{O}$ & $1 \mathrm{~mm}$ & $\mathrm{C}$ & $\mathrm{P}$ & S & HQ641243 \\
\hline BR3366 & $5 \mathrm{YO}$ & $S$ & AL & FL & $\mathrm{W}$ & $\mathrm{He}$ & $\mathrm{O}$ & $>1 \mathrm{~mm}$ & $\mathrm{C}$ & $\mathrm{P}$ & S & HQ641244 \\
\hline BR3367 & $5 \mathrm{YO}$ & S & AL & FL & W & $\mathrm{He}$ & $\mathrm{O}$ & $2 \mathrm{~mm}$ & I & $\mathrm{P}$ & S & HQ641245 \\
\hline BR3368 & $5 \mathrm{YO}$ & $S$ & AL & FL & $\mathrm{W}$ & $\mathrm{He}$ & $\mathrm{O}$ & $>1 \mathrm{~mm}$ & I & $\mathrm{P}$ & S & HQ641246 \\
\hline BR3369 & $5 \mathrm{YO}$ & $S$ & $\mathrm{AL}$ & FL & W & $\mathrm{He}$ & $\mathrm{O}$ & $>1 \mathrm{~mm}$ & $\mathrm{C}$ & $\mathrm{P}$ & S & HQ641247 \\
\hline BR3370 & $5 \mathrm{YO}$ & $\mathrm{S}$ & $\mathrm{AL}$ & FL & $\mathrm{W}$ & $\mathrm{He}$ & $\mathrm{O}$ & $2 \mathrm{~mm}$ & I & $\mathrm{P}$ & S & HQ641248 \\
\hline BR3373 & $5 \mathrm{YO}$ & $\mathrm{S}$ & $\mathrm{AL}$ & FL & W & $\mathrm{He}$ & $\mathrm{O}$ & $>1 \mathrm{~mm}$ & $\mathrm{C}$ & $\mathrm{P}$ & $\mathrm{S}$ & HQ641249 \\
\hline
\end{tabular}

The areas: $5 \mathrm{YOE}=5$ years old enriched with native species, $18 \mathrm{YO}=18$ years old reclamation area, $\mathrm{MO}=$ monoculture plot, $\mathrm{NF}=$ native forest, $5 \mathrm{YO}=5$ years old reclamation area and $\mathrm{PO}=$ polyculture plot. The morphological traits: $\mathrm{GR}=$ growth rate $(\mathrm{F}=$ fast and $\mathrm{S}=$ slow $), \mathrm{pH}=$ change of the medium $(\mathrm{AL}=$ alkaline, $\mathrm{AC}=$ acid, $\mathrm{N}=$ neutral $), \mathrm{CM}=\mathrm{consistency}$ of mucous $(\mathrm{FL}=$ floccular, $\mathrm{V}=$ viscous $), \mathrm{TM}=$ type of mucous $(\mathrm{W}=$ wet, $\mathrm{D}=$ dry $), \mathrm{AM}=$ appearance of mucous $(\mathrm{He}=$ heterogeneous, Ho = homogeneous $), \mathrm{O}=\mathrm{optics}(\mathrm{O}=\mathrm{opaque}, \mathrm{T}=$ translucent, $\mathrm{O} / \mathrm{T}=$ translucent with the center of colony opaque $), \mathrm{D}=$ diameter $(\mathrm{mm}), \mathrm{F}=$ form $(\mathrm{C}=$ circular, $\mathrm{I}=$ irregular $), \mathrm{E}=$ elevation $(\mathrm{P}=$ plain, $\mathrm{E}=\mathrm{elevated})$ and $\mathrm{B}=$ border $(\mathrm{S}=$ smooth, $\mathrm{R}=$ rough). 


\section{ARDRA analysis}

Twenty one Amazon isolates from 12 previously characterized cultural groups and four reference strains BR33 or CB 1809 (Bradyrhizobium japonicum), BR29 or SEMIA 5019, BR96 or SEMIA587 and BR2001 or SEMIA 6145 (Bradyrhizobium elkanii) obtained from the diazotroph culture collection of Embrapa Agrobiologia were grown in YMA. Total DNA was extracted (22) and the 16S rDNA ribosomal gene was amplified using universal primers Y1 (26) and Y3 (12) that amplify approximately $1500 \mathrm{bp}$ of the $16 \mathrm{~S}$ rDNA. PCR reactions were prepared as described before (26). The ARDRA analysis was performed using the restriction enzymes HinfI, DdeI and MspI (11). The reference isolates were used for 16S rRNA gene polymorphic profiles comparison. Jaccard Index and UPGMA (Unweighted Pair-Group Method) algorithm, available in the PAST program, version 1.92 (6), were used to build dendrogram.

\section{Sequencing analysis}

Sixty three Amazon isolates from previously characterized cultural groups were selected for sequencing of $16 \mathrm{~S}$ rRNA gene. The isolates were grown on YMA medium and the colonies were suspended in sterile distilled water and hold for $10 \mathrm{~min}$. at $8.000 \mathrm{RPM}$. The precipitate was submitted to the DNA phenol extraction. The $16 \mathrm{~S}$ rRNA gene was amplified using the primers Y1 and Y3. The amplification product was precipitated with $\mathrm{NaCl}(5 \mathrm{M})$ and $70 \%$ ethanol and sequenced in automatic DNA Sequencer MegaBACE1000 (GE). Six different primers distributed along the $1500 \mathrm{bp}$ 16S rRNA gene fragment were used in the sequencing reactions (Table 2).

Table 2. Primers used in the $16 \mathrm{~S}$ rDNA sequencing reactions.

\begin{tabular}{llc}
\hline Primers & Sequence $\mathbf{5}^{\prime} \rightarrow \mathbf{3}^{\prime}$ & Reference \\
\hline Y1 & TGGCTCAGAACGAACGCTGGCGGC & 26 \\
Y2 & CCCACTGCTGCCTCCCGTAGGAGT & 26 \\
Y3 & CTGACCCCACTTCAGCATTGTTCCAT & 12 \\
$16 S 362 \mathrm{f}$ & CTCCTACGGGAGGCAGTGGGG & 21 \\
$16 \mathrm{~S} 786 \mathrm{f}$ & CGAAAGCGTGGGGAGCAAACAGG & 21 \\
$16 \mathrm{~S} 1203 \mathrm{r}$ & GAGGTGGGATGACGTCAAGTCCTC & 21 \\
$16 \mathrm{~S} 1110 \mathrm{r}$ & TGCGCTCGTTGCGGGACTTAACC & 21 \\
$16 \mathrm{~S} 805 \mathrm{r}$ & GACTACCAGGGTATCTAATCCTG & 21 \\
\hline
\end{tabular}

The sequences obtained for Amazon isolates were deposited in the GenBank and gained accession numbers (Table 1). The sequences of the following type and reference strains were used for phylogenetic comparison: Bradyrhizobium sp. S6163 (AY904764), Bradyrhizobium sp. BR3267 (AY649439), Bradyrhizobium yuanmingense CCBAU10071 $^{\mathrm{T}}$ (AB509380), Bradyrhizobium sp. BR3287 (AY649442), B. betae PL7HG1 ${ }^{\mathrm{T}}$ (AY372184.1), B. japonicum S6002 (AY904743), B. liaoningense USDA3622 (AB510000), B. canariense BTA- $1^{\mathrm{T}}$ (AJ558025), B. japonicum USDA $6^{\mathrm{T}}$ (U69638), B. japonicum S5079 (AF2344888), B. elkanii S587 (AF234890), B. elkanii S6175 (AY904771), B. elkanii USDA76 ${ }^{\mathrm{T}}$ (U35000), B. elkanii S662 (AY904734),
Methylobacterium sp. S658 (AY904733), Azorhizobium sp. (AY904783), Mesorhizobium ciceri (EF611374), Rhizobium tropici (U89832), Sinorhizobium meliloti (Ensifer) (X67222), Burkholderia sp. $56166 \quad$ (AY904767), Rhizobium leguminosarum (U29386), Rhizobium etli (U28916), Agrobacterium rhizogenes (D14501), Sinorhizobium fredii (Ensifer) (X67231), Mesorhizobium loti (X67229), Klebsiella sp. (HQ264076) and Enterobacter sp. (FN433019).

The sequence alignment was done using the Clustal W (23) and manually edited using the Bioedit package (5). The cladograms were constructed by Neighbor-Joining method (20) with the Kimura-2-parameter model (9) and were bootstrapped using the software programs in the MEGA 3.1 package (10). 
The numbers, in the cladograms indicate how many times each sequence grouped in determined position during the analysis.

\section{RESULTS AND DISCUSSION}

In this present work, a study about the genetic diversity and phylogenetic positioning of rhizobia was done from a collection of 188 Amazon isolates. They were clustered into forty morphological and cultural groups (data not shown). The number of isolates from each studied area was: 32 from native forest, 31 from 18 years old reclamation area, 32 from 5 years old reclamation area, 34 from 5 years old reclamation area enriched with native species, 29 from polyculture and 30 from monoculture.

The genetic characterization for the Amazon isolates was done by ARDRA technique and twenty one isolates representatives of twelve cultural groups were chosen from a dendrogram based on their morphological and cultural characteristics (data not shown). The origin, morphological and cultural characteristics of the isolates analyzed by ARDRA is described on Table 1. The restriction profiles analysis obtained for all the Amazon isolates with the enzymes MspI and DdeI were the same but HinfI detected differences that separated them into three subgroups. Isolates that had identical rDNA genotypes did not display similar phenotypic characteristics (3) and it was corroborated by our results. In the dendrogram (Figure 1), the first subgroup of Amazon isolates assembled 16 isolates from 10 cultural groups with $100 \%$ of similarity; the second grouped 4 isolates from 4 cultural groups, also with $100 \%$ of similarity and the third was composed by only one isolate.

Despite the 16S rRNA gene is efficient to define genera because it is conserved but have variable regions; it has also limitations to identify species, due to possible occurrence of genetic recombination and horizontal gene transfer (18). In addition, when the sequences of $16 \mathrm{~S}$ rDNA of $B$. liaoningense and B. japonicum were compared, it was revealed that although these bacteria are phenotypically different they are genotypically highly related (24). The ARDRA method has efficiency in genetic characterization and diversity study of rhizobia $(30,2)$ and it was corroborated by ours results since the isolates from the same cultural group, for example, (BR3306 and BR3309), (BR3307 and BR3310) and (BR3353, BR3316 and BR3336) were separated into first and second subgroups (Figure 1). It means that genetic diversity was detected by ARDRA technique, although it is not always able to separate species that are closely related (3). The restriction profiles obtained with the three enzymes HinfI, MspI and DdeI pointed differences among the reference isolates which separated the Amazon isolates from the Bradyrhizobium japonicum (BR33) with $70 \%$ of similarity and from the Bradyrhizobium elkanii (BR29, BR96, BR2001) strain with $50 \%$ of similarity (Figure 1). There was no relationship between the ARDRA groupings and the origin of the isolates as observed by others authors (30). A fast-growing isolate (BR3304) that changes the $\mathrm{pH}$ of the medium to alkaline was also related to Bradyrhizobium.

The 16S rRNA gene sequencing, which is widely used for molecular phylogeny of rhizobia (15), was chosen as a second strategy to better evaluate the diversity and phylogenetic positioning of Amazon isolates. At this point, sixty three isolates representative of the forty cultural groups from the collection were selected from a dendrogram based on cultural characteristics (data not shown). The 16S rDNA from these isolates was amplified using Y1 (26) and Y3 (12) primers, which allowed the amplification of almost complete gene: 1380 $\mathrm{bp}$ for the fast-growing and $1440 \mathrm{bp}$ for the slow-growing after trimming low quality regions. Although the PCR products were sequenced successively in both directions, using $\mathrm{Y} 1 / \mathrm{Y} 3$ and more six different primers (Table 2), thirteen isolates were not completely sequenced after several sequence reactions. Therefore, fifty isolates, representatives of twenty seven cultural groups, were sequenced and then used in phylogenetic analysis. The origin, morphological and cultural characteristics of the fifty isolates analyzed by sequencing were described (Table 1). 


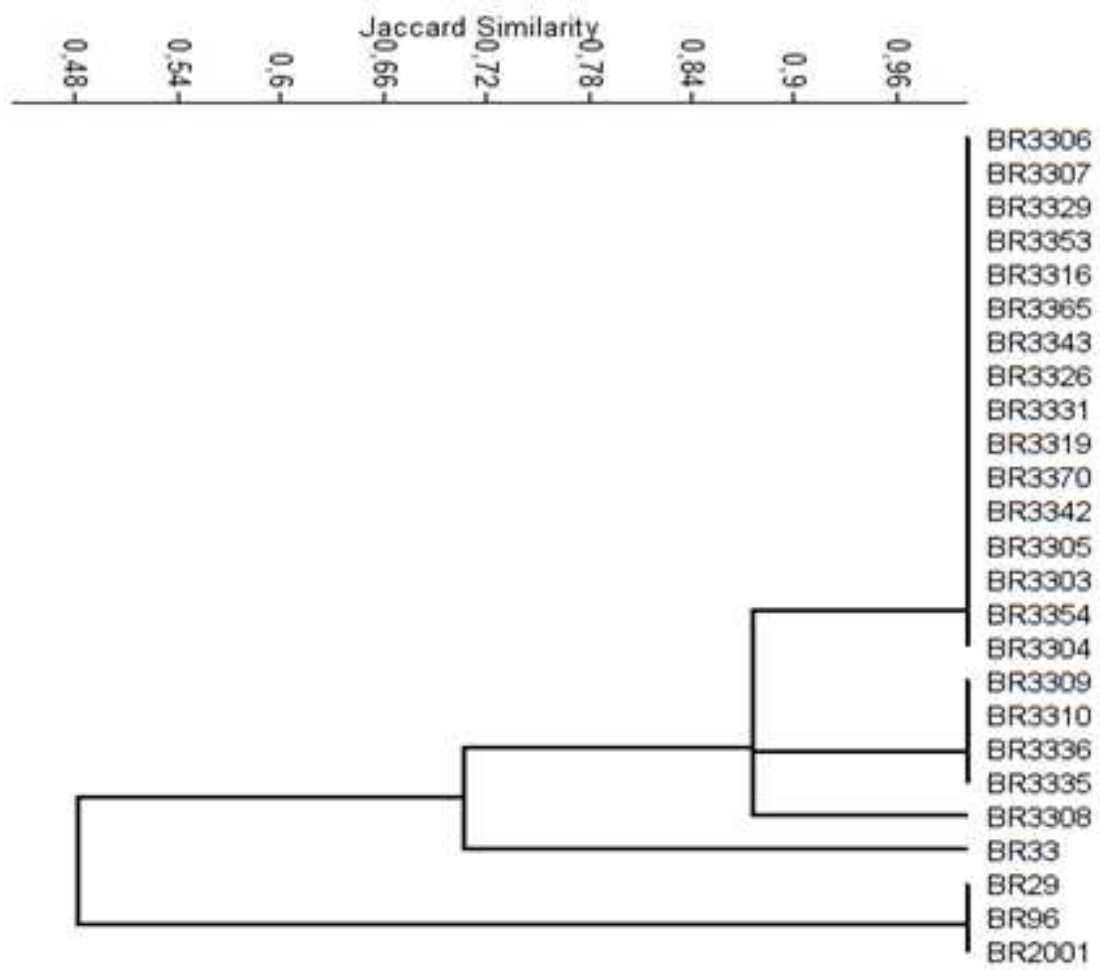

Figure 1. UPGMA dendrogram, constructed from ARDRA profiles of both, the 16S rRNA gene of Amazon isolates and reference strains of Bradyrhizobium. Scale bar indicates percentage of Jaccard similarity coefficient.

The fast-growing isolates (BR3304, BR3337 and BR3352) had high similarity with Bradyrhizobium corroborating the ARDRA analysis (Figure 2). In the literature, the Bradyrhizobium isolates have shown slow-growing or fastgrowing characteristics $(22,3)$.

The 16S rRNA sequences of others fast-growing isolates (Figure 2) showed similarity with Enterobacter sp., Rhizobium sp. and Klebsiella sp. and it corroborates the results obtained before (7) that showed similarity of the $16 \mathrm{~S}$ rDNA sequences of fast-growing isolates from root nodules of Arachis hypogaea with Pseudomonas spp., Enterobacter spp. and Klebsiella spp. The authors defended the idea that these isolates were opportunistic bacteria that colonize nodules induced by rhizobia.

The 16S rRNA sequences of the Amazon isolates showed they form a cluster with SEMIA 6163 isolated from Acacia mearnsii in Brazil, and previously classified as Bradyrhizobium sp. (15) with a bootstrap value of 74 and close to Bradyrhizobium type strains and reference isolates (Figure 3). Genetic diversity of the $16 \mathrm{~S}$ rRNA was detected among the Amazon isolates and the subgroups based on sequencing were formed by isolates that are not identical in relation to their morphological and cultural characteristics. In addition, the comparison of sequencing results to those obtained by ARDRA, showed that the isolates clustered in the same subgroup of ARDRA analysis (Figure 1), were separated by the clustering of $16 \mathrm{~S}$ rRNA sequences (Figure 3 ). The reason for this is that the ARDRA analysis is based only in the presence or absence of restriction sites inside the gene, while the sequencing compares all the bases of the sequences aligned. There was no relation between the sequencing groupings and the origin of the isolates as observed in the ARDRA analysis.

The BR3267, from semi-arid area of Pernambuco state and actually recommended as cowpea inoculants was grouped 
with $B$. yuanmingense with a bootstrap of 84 , which could be an indication of its classification. This isolate was classified before as Bradyrhizobium sp., but it was not compared to $B$. yuanmingense (31). B. yuanmingense is one of the main rhizobia associated with Vigna unguiculata (29). The reference isolates BR3287 (Bradyrhizobium sp) from Cerrado soils (31), B. betae type strain, SEMIA 6002 (B. japonicum) from Zimbabwe (15), B. liaoningense and B. canariense were also separated. The reference isolate S5079 clustered with $B$. japonicum type strain with a bootstrap of 89 and S587, S6175 and S662 clustered with B. elkanii with a bootstrap of 99 corroborating their previous classification (15). All other genera were separated as outgroups.

A fact that should be considered is that many species of Bradyrhizobium have divergences of 16S rRNA sequence that varies from 0.1 to $2 \%$ (25) and it was more difficult to show the genetic diversity among them since this gene provided poor resolution at the species level of this genera. Considering a report that combined the sequencing of $16 \mathrm{~S}$ rRNA and other gene to improve the knowledge of rhizobia classification (18), it is not possible to affirm that the Amazon isolates are new species. Additional studies using different genes and/or a genomic approach are necessary to better characterize these isolates.

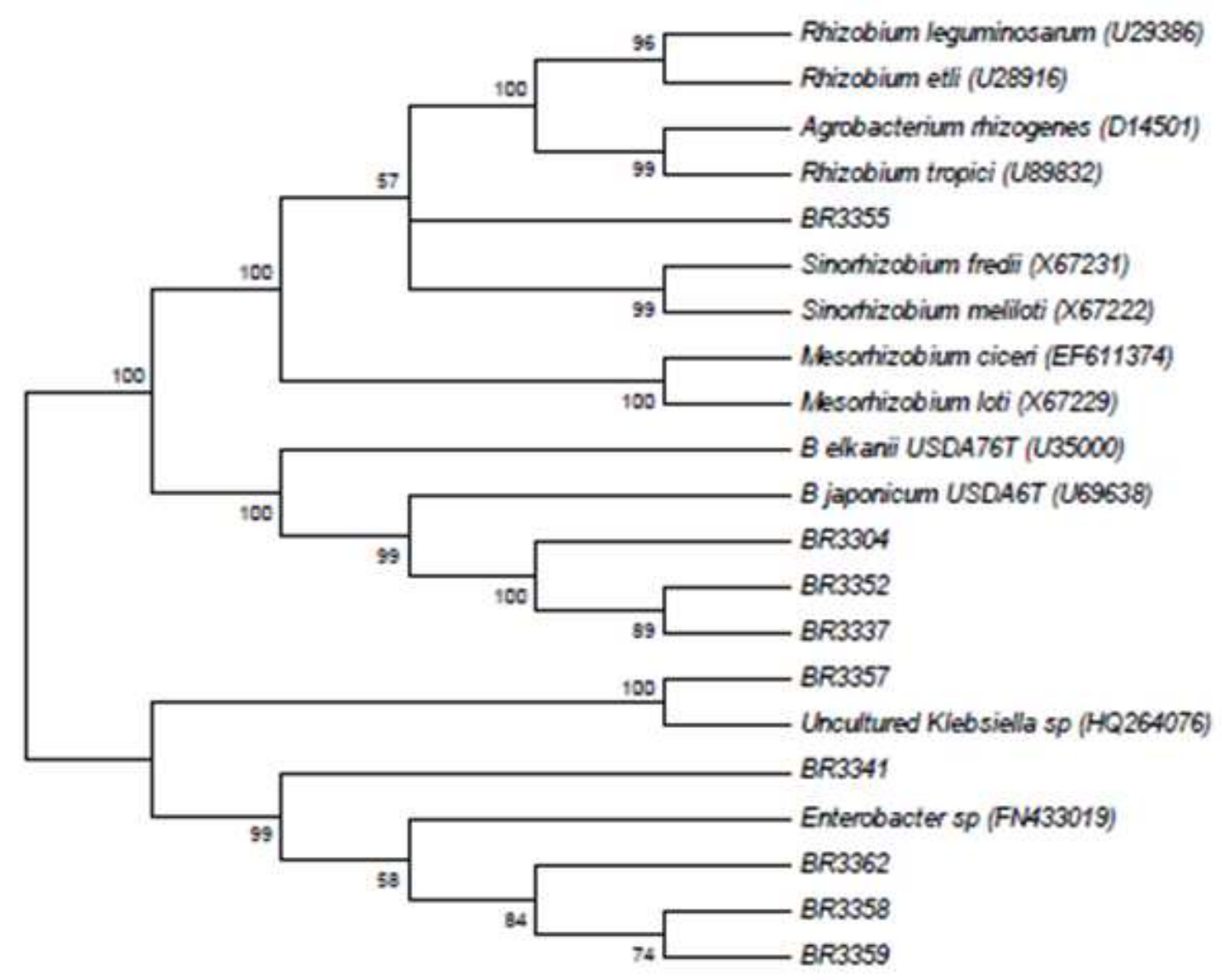

Figure 2: Neighbor-joining tree obtained using Kimura-2-parameter distances based on 16S rRNA sequences data of fast-growing isolates from Amazon soils and rhizobia reference strains. 


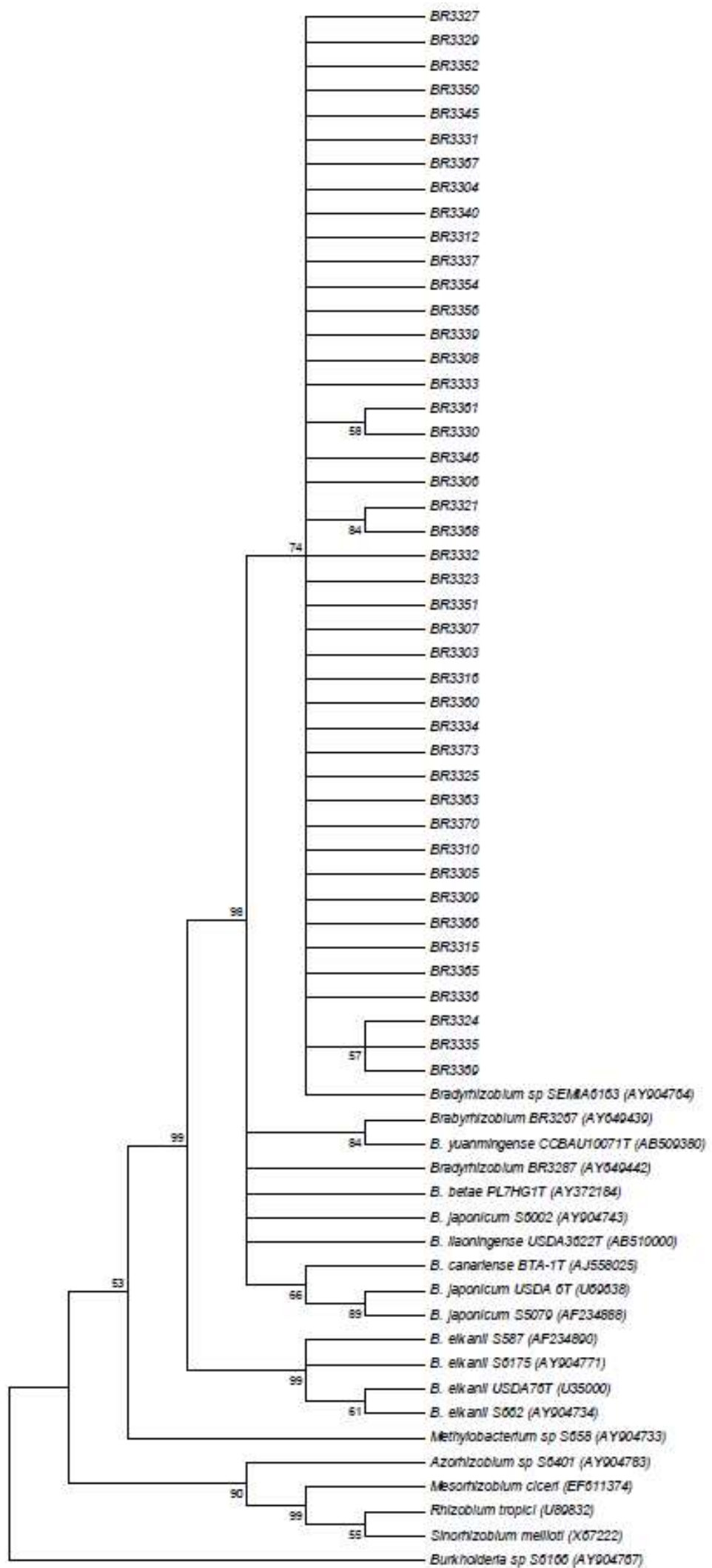

Figure 3. Neighbor-joining tree obtained using Kimura-2-parameter distances based on 16S rRNA sequences data of isolates from Amazon soils and rhizobia reference strains. 


\section{ACKNOWLEDGEMENTS}

The authors would like to thank CAPES, CNPq, EmbrapaAgrobiologia and Embrapa-Agrofloresta for financial support.

\section{REFERENCES}

1. Chagas Junior, A.F.; Oliveira, L.A.; Oliveira, A.N. (2009). Caracterização genética de rizóbio isolados de solos no Amazonas baseada na técnica de PCR-RFLP. Semina. Ciên Agrar, 30, 841-846.

2. Fening, J.O.; Sessitsch, A.; Offei, S.K.; Danso, S.K.A. (2004). Genomic heterogeneity within cowpea bradyrhizobia from Ghanaian soils. West African Journal of Applied Ecology, v.6, 20-29.

3. Fernandes, M.F.; Fernandes, R.P.M.; Hungria, M. (2003). Caracterização genética de rizóbios nativos dos tabuleiros costeiros eficientes em culturas do guandu e caupi. Pesqui Agropecu Bras, 38, 8, 911-920.

4. Fred, E.B., Walksman, S.A. (1928). Yeast Extract - Manitol Agar Laboratory Manual of General Microbiology. New York: McGraw Hill.

5. Hall, T.A. 1999. BioEdit: a user-friendly biological sequence alignment editor and analysis program for Windows 95/98/NT. Nucl. Acids. Symp. Ser. 41:95-98.

6. Hammer, Ø., Harper, D.A.T., and P. D. Ryan. PAST: Paleontological Statistics Software Package for Education and Data Analysis. Palaeontologia Electronica, 4(1): 9p., 2001.

7. Ibanez, F.; Angelini, J.; Taurian, T.; Tonelli, M.L.; Fabra, A. (2009). Endophytic occupation of peanut root nodules by opportunistic Gammaproteobacteria. Syst Appl Microbiol, 32, 1, 49-55.

8. Jesus, E.C.; Moreira, F.M.S.; Florentino, L.A.; Rodrigues, M.I.D.; Oliveira, M.S. (2005). Diversidade de bactérias que nodulam siratro em três sistemas de uso da terra da Amazônia Ocidental. Pesqui Agropecu Bras, 40, (8), 769-776.

9. Kimura, M. (1980). A simple method for estimating evolutionary rates of base substitutions through comparative studies of nucleotide sequences. $J$ Mol Evol 16, 111-120.

10. Kumar S., Tamura K., Nei, M. (2004) MEGA 3: integrated software for molecular evolutionary genetics analysis and sequence alingment. Brief Bioinforms. 5: 150-163.

11. Laguerre, G.; Mavingui, P.; Allard, M. R.; Charnay, M. P.; Louvrier, P.; Mazurier, S. I.; Rigottier-Gois, L.; Amarger, N. (1996). Typing of rhizobia by PCR-DNA fingerprinting and PCR-restriction fragment length polymorphism analysis of chromosomal and symbiotic gene regions: Application to Rhizobium leguminosarum and its different biovars. Appl Environ Microbiol, v. 62, 2029-2036.

12. Laranjo, M., Machado, J., Young, J.P.W., Oliveira, S. (2004). High diversity of chickpea Mesorhizobium species isolated in a Portuguese agricultural region. FEMS Microbiol Ecol, 48:1, 101-107.

13. Lima, A.S.; Pereira, J.P.A.R.; Moreira, F.M.S. (2005). Diversidade fenotípica e eficiência simbiótica de estirpes de Bradyrhizobium sp. isoladas de solos da Amazônia. Pesqui Agropecu Bras, 40, (11), 10951104.

14. Lindstrom, K.; Young, J.P.W. (2009). International Committee on Systematics of Prokariotes. Subcommittee on the taxonomy of Agrobacterium and Rhizobium. Int J Syst Evol Microbiol, 59, 921-922.

15. Menna, P.; Hungria, M.; Barcellos, F.G.; Bangel, E.V.; Hess, P.N.; Martinez-Romero, E. (2006). Molecular phylogeny based on the $16 \mathrm{~S}$ rRNA gene of elite rhizobia strains used in Brazilian commercial inoculants. Syst Appl Microbiol, 29, 315-332.

16. Moreira, F.M.S.; Haukka, K.; Young, J.P.W. (1998). Biodiversity of rhizobia isolated from a wide range of forest legumes in Brazil. Mol Ecol, 7, 889-995.

17. Moreira, F.M.S. Estirpes de bactérias altamente eficientes que fornecem nitrogênio para o caupi foram selecionadas na UFLA e já são recomendadas para produção de inoculantes comerciais. Available at: (www.dcs.ufla.br/artigocaupi.pdf). Accessed 25 November 2008.

18. Neto, I.V.R.; Ribeiro, R.A.; Hungria, M. (2010). Genetic diversity of elite rhizobial strains of subtropical and tropical legumes based on the $16 \mathrm{~S}$ rRNA and glnII genes. World J Microbiol Biotechnol, 26, 1291 1302.

19. Norris, D.O.; 't Mannetje, L. The symbiotic specialization of African Trifolium spp. In relation to their taxonomy and their agronomic use. East African Agricultural and Forestry Journal, v.29, p.214-235, 1964.

20. Saitou, N. and Nei, M. (1987). The neighbor-joining method: a new method for constructing phylogenetic trees. Mol. Biol. Evol., 4, 406-425.

21. Soares-Ramos, J.R.L.; Ramos, H.J.O.; Cruz, L.M.; Chubatsu, L.S.; Pedrosa, F.O.; Rigo, L.U.; Souza, E.M. (2003). Comparative molecular analysis of Herbaspirillum strains by RAPD, RFLP, and 16S rDNA sequencing. Genet Mol Biol, 26 (4): 537-543.

22. Teixeira, F.C.P.; Borges, W.L.; Xavier, G.R.; Rumjanek, N.G. (2010). Characterization of indigenous rhizobia from caatinga. Braz J Microbiol, 41, 201-208.

23. Thompson, J.D.; Higgins, D.G.; Gibson, T.J. (1994). CLUSTALW: improving the sensitivity of progressive multiple sequence alignment through sequence weighting, position-specific gap penalties and weight matrix choice. Nucleic Acids Res., 22: 4673-4680.

24. Willems, A.; Coopman, R.; Gillis, M. (2001). Phylogenetic and DNADNA hybridization analyses of Bradyrhizobium species. Int J Syst Evol Micr, 51, 111-117.

25. Willems, A. (2006). The taxonomy of rhizobia: an overview. Plant Soil, 287, 3-14.

26. Young, J.P.W.; Downer, H.L.; Eardly, B.D. (1991). Phylogeny of the Phototrophic Rhizobium Strain BTAil by Polymerase Chain ReactionBased Sequencing of a 16S rRNA Gene Segment. J Bacteriol, 173, (7), 
2271-2277.

27. Young, J. M., Kuykendall, L. D., Martínez-Romero, E., Kerr, A., Sawada, H. (2001). A revision of Rhizobium Frank 1889, with an emended description of the genus, and the inclusion of all species of Agrobacterium Conn 1942 and Allorhizobium undicola de Lajudie et al. 1998 as new combinations: Rhizobium radiobacter, $R$. rhizogenes, $R$. rubi, R. undicola and R. vitis. Int. J. Syst. Evol. Microbiol, 51, 89-103.

28. Young, J.M. (2010). Sinorhizobium versus Ensifer: may a taxonomy subcommittee of the ICSP contradict the Judicial Commission? Int. J. Syst. Evol. Microbiol, 60, 1711-1713.

29. Zhang, Y.Z.; Wang, E.T.; Tian, C.F.; Wang, F.Q.; Han, L.L.; Chen,
W.F.; Chen, W.X. (2008). Bradyrhizobium elkanii, Bradyrhizobium yuanmingense and Bradyrhizobium japonicum are the main rhizobia associated with Vigna unguiculata and Vigna radiata in the subtropical region of China. FEMS Microbiol Lett, 285, 146-154.

30. Zilli, J.E.; Valisheski, R.R.; Freire Filho, F.R.; M.C.P.; Rumjanek, N.G. (2004) Assesment of cowpea rhizobium diversity in cerrado areas of northeastern Brazil. Braz. J. Microbiol., 35, 281-287.

31. Zilli, J.E., Valicheski, R.R., Rumjanek, N.G., Simões-Araújo, J.L., Filho, F.R.F., Neves, M.C.P. (2006). Eficiência simbiótica de estirpes de Bradyrhizobium isoladas de solo do Cerrado em caupi. Pesqui Agropec Bras, 41, 5, 811-818. 